\title{
Planning the Conversion of a College to a University Library
}

\begin{abstract}
Many new university libraries are being rapidly developed out of older, small college collections. Methods and standards available for the planning of such libraries include the Clapp-Jordan formula for book collections and standards for buildings and book collections used by the State of California. Professor Robert Hayes of the school of library service, UCLA, is preparing a formula for the development of collections in University of California libraries. Methods used in planning for the development of the University of California library, Davis, are described.
\end{abstract}

$\mathrm{T}$ HE PAINFULLY SUDDEN and explosive development of many small, usually bucolic, undergraduate and specialized colleges into full-scale universities in this country and abroad has been a remarkable phenomenon since World War II. Some institutions have literally doubled their enrollment annually over a period of years with student bodies increasing from a few hundred to ten or twenty thousand persons in a relatively short period. In addition, numerous and completely new colleges and universities with great aspirations and mostly hope for assets have been started in tropical forests, asphalt jungles, raw prairies, and in the mazes of suburbia. In several notable cases new satellite campuses have been seeded by existing older campuses.

It is clear that all over the world, including the United States, there is a great need for thorough planning, based on reasonable standards and guidelines,

Mr. Blanchard is University Librarian at the University of California, Davis. This paper was prepared for presentation to officers of the Rockefeller Foundation. in connection with the library systems of such new and rapidly growing institutions. Standards for library buildings have been available. Planning for book collections and library services has been difficult as there has not been available in the past well devised, clearly defined, and widely accepted standards and guidelines. Fortunately, the Clapp-Jordan $^{1}$ formula for book collections, which has now been widely promulgated, will be useful as will other recent efforts to create meaningful standards.

Before library standards can be used, however, an institution must first make basic decisions about its purpose, academic program, and size. The various factors that have a bearing on library needs listed in order of priority include the following.

1. The academic program. Undergraduate programs require relatively small library collections. Graduate programs, particularly at the doctoral level, require heavy investments in large book collec-

1 Verner Clapp, and Robert T. Jordan, "Quantitative Criteria for Adequacy of Academic Library Collections," CRL, XXVI (September 1965), 371-80. 
tions. According to a recent survey ${ }^{2}$ at the Joint University Libraries, graduate students and faculty there require library services costing 4.8 times more than undergraduates.

2. Quality. This is a factor that is hard to determine. The fact that a good library is important in relation to the quality of an institution is widely accepted and was clearly noted in an important study recently published by the American Council on Education. ${ }^{3}$

3. Size of enrollment. This factor must be considered, but it should rank below the academic program and quality as a factor, particularly as far as book collections are concerned. Institutions should not plan library facilities based largely on the size of the enrollment.

4. Other library facilities available in the area. Too much weight is often given to this factor. An institution must eventually develop a library to meet its basic needs and other libraries if available should only be depended upon for seldom-used special materials and for the partial support of certain research projects.

Once the above factors have been determined, long range library plans should be prepared which include estimates of needs for book collections, space, staff, and funds.

As a case study, it should be useful to examine the methods by which planning for educational institutions and libraries has been undertaken by the State of California. The urgent need for greatly expanded educational facilities in California became obvious shortly after World War II and resulted in three very important and seminal planning documents. ${ }^{+}$These studies showed clearly

\footnotetext{
${ }^{2}$ Unpublished report by the Joint University Libraries (Nashville, Tennessee).

${ }^{3}$ Allan M. Cartter, An Assessment of Quality in Graduate Education (Washington, D.C.: American Council on Education, 1966).

${ }^{4}$ California. Committee on the Conduct of the Study of Higher Education in California. A Report of a Survey of the Needs of California in Higher Educa-
}

that great quantities of new students would soon inundate the state's institutions of higher education and that it was mandatory to enlarge existing colleges and universities and to start new ones. The last and most important of the studies, A Master Plan for Higher Education in California, 1960-1975, resulted in legislation which officially recognized California's higher education system which is based on junior municipal colleges, state colleges, the university, and independent colleges. Each type of state-supported institution has a specific task although there is much overlapping of function. Entrance requirements vary from the junior colleges, which accept graduates of all accredited high schools, to the university, which accepts about the upper 12 per cent of high school students. Junior colleges prepare students for vocations as well as for transfer to the state colleges and universities. The state colleges provide general academic work through the master's degree in most basic disciplines and also train many of the teachers for the state. Besides a general curriculum, the university gives particular attention to graduate work, research, and professional training in such fields as law and medicine. Total enrollments in 1958 were 225,615 with 661,350 expected by 1975 . There are now nine general campuses of the university as compared to two, Berkeley and UCLA, in 1951. State colleges have grown to about seventeen.

The studies gave little specific attention to libraries. However, in the Restudy of the Needs of California in Higher Education the following guidelines were recommended.

1. Library reading stations for one-

tion Submitted to the Liaison Committee of the Regents and the State Department of Education (The Strayer report, Sacramento, 1948); Liaison Committee of the Regents of the University of California and the California State Board of Education. A Restudy of the Needs of California in Higher Education (Sacramento, 1955); A Master Plan for Higher Education in California, 1960-1975: (Sacramento, 1960). 
fourth the students should be provided. Thirty net square feet per station should be allowed which would also provide for library work space.

2 . .10 net square feet of space per volume for the first 150,000 volumes decreasing to .05 net square feet for the second one million volumes.

3. State colleges: Thirty volumes for each full-time student for the first 5,000 students plus twenty volumes for each full-time student beyond 5,000 students. University: one hundred volumes per student for the first 10,000 , seventy-five volumes for the second 10,000 , fifty volumes per student beyond 20,000 .

These guidelines were admittedly rule of thumb and were devised quickly by an advisor who based them on library facilities and collections as they existed at certain institutions. Although they were partially inadequate, they were used as standards for several years and still have much authority. As far as the university is concerned, they were replaced in part by A Plan for Library Development ${ }^{5}$ issued in 1961, prepared at the request of President Kerr, and the Unit Area Allowance for Libraries ${ }^{6}$ prepared by a special committee of librarians and architects in 1966.

Within the University of California system the Davis campus represents very well the growth of a specialized campus into a general university. An examination of its library development might be fruitful in coming to conclusions about how library planning in such a situation should be handled and what mistakes should be avoided.

From 1909 to 1951 Davis was a college of agriculture started originally as an offshoot of the Berkeley campus. In 1951 a College of Letters and Science was initiated at a very modest level. At

${ }^{5}$ California. University. Office of the President, A Plan for Library Development. 1961.

${ }^{8}$ California. University. Committee on Library Space Standards. Unit Area Allowances for Libraries. 1966. that time, Davis had about eighteen hundred students, all in agriculture except for a handful in the College of Letters and Science. The academic program in agriculture was a strong one with a doctorate provided. Major emphasis was placed on research. The library had eighty thousand well selected volumes, about 80 per cent of which were concerned with the biological sciences and agriculture. No firm, long-range plan had as yet been prepared for the library or the campus in general. It was assumed, however, that the College of Letters and Science would remain small and would emphasize the basic sciences. With these limitations in mind, efforts of the library staff for the next few years were largely focused on building up the scientific collection, although some attention was given to basic material needed for the social sciences and humanities. Much dependence in these years was placed on the large university library at Berkeley.

Library growth was accelerated in 1959 when Davis was designated a general campus. At about that time an acquisitions code was devised for the library which emphasized that the development of the book collection should be based on the academic program. A library long-range building program was prepared. Unfortunately, both of these documents were based on inadequate information about the future academic development of the campus, which was still somewhat uncertain. By 1961 it became clear that Davis would become a general university in fact as well as name, that graduate work in practically all basic disciplines was to be provided, and that professional schools of law, medicine, engineering, and possibly two or three others would be created. It was also at this time that the previously noted $A$ Plan for Library Development was issued which stated that Davis and the other emerging general campuses of the Uni- 
versity should have at least five hundred thousand volumes on hand by the year 1970-71. This figure for Davis was later increased by President Kerr to nine hundred thousand volumes. Using this document, plus a published academic plan for the Davis campus, it was now possible for the library staff to do its planning work with some assurance. The planning had four principal aspects:

Collection Development. It was agreed at the beginning that selection of material should be a joint faculty and library staff endeavor. Subject specialists on the library staff worked with faculty members in preparing want lists based on standard bibliographies and the needs of the academic program. Goals for the numbers of volumes to be processed each year up to 1970-71 were estimated. Priority in the expenditure of book funds was given to the needs of new graduate and professional programs particularly in the fields not formerly emphasized on the campus.

No acceptable quantitative factors for estimating the size of book collections were available in 1961. However, Professor Robert Hayes of the University of California's Institute of Library Research is now developing a set of factors based in part on the Clapp-Jordan formula and experience at the University of California. Librarians at the Davis campus in preparing material for Professor Hayes reached the following conclusions about quantitative factors.

1. A basic core collection should be developed of at least fifty thousand volumes, but preferably consisting of seventy-five thousand or even one hundred and twenty-five thousand volumes. The Clapp-Jordan formula suggests an "undergraduate library" as a starting point with a minimum of fifty thousand seven hundred and fifty volumes. The core collection would include general reference works, bibliographies, volumes supporting basic general reading require- ments and a general periodicals collection (assuming that bound periodical backfiles would be counted as monographic volumes). Selections for this basic library could be based in part on lists prepared for the University of Michigan's undergraduate library ${ }^{7}$ and for the new campus program of the University of California. ${ }^{8}$ The latter program involved the simultaneous development of basic undergraduate libraries of seventy-five thousand volumes each for the new San Diego, Irvine and Santa Cruz campuses.

2. Additional volumes should be added for each academic program as follows.

a. Seventy-five thousand volumes for each new college and professional school.

b. Approximately one thousand to fifteen hundred volumes for each undergraduate major. The Clapp-Jordan study recommends three hundred and thirtyfive volumes for each baccalaureate program. However, the Davis librarians believe these requirements should be higher particularly for programs that include fields with high literature requirements such as history, English literature, and political science.

c. About five thousand volumes for each master's program and twenty-five thousand volumes for each doctoral program. The Clapp-Jordan formula calls for three thousand and twenty-four thousand five hundred volumes respectively for master's and doctoral programs.

3. Volumes needed based on student enrollment. It is recommended that approximately ten volumes be added for each undergraduate student and twenty volumes for each graduate student. As stated earlier, book collection requirements must largely be based on the academic program; however, additional

\footnotetext{
- Michigan. University. Library. Undergraduate shelf list to December 30, 1963 (Ann Arbor: University Microfilms [on microfilm, cards, and xerox]).

*Melvin J. Voigt, and Josenh H. Treyz, Books for College Libraries (Chicago: Ar.A, 1967).
} 
copies of basic works are required as the student enrollment grows.

4. Volumes needed based on the number of faculty members and research in the institution. It is recommended that about 200 volumes for each faculty member and 100 volumes for each professional research staff member be added by the library.

Library organization. It was decided early in the planning stage that the library's organization and services should be centralized as much as possible if the funds available were to be used effectively. The chancellor issued a statement that new departmental libraries could not be started or older ones appreciably enlarged without the consent of the university librarian and the chancellor. This unequivocal statement has been of great value. A policy statement was also issued by the president of the university that all campus libraries on each campus were to be under the jurisdiction of the respective university librarians. Each university librarian was made a member of the academic senate and all professional librarians were shifted from nonacademic to academic status. Clarification of these matters greatly strengthened the hand of the library staff in developing a strong centralized library system.

Staffing. Planning for staff has usually been the weakest part of library development programs and Davis has been no exception. Administrators may believe that if book money and buildings are provided everything else will follow along automatically. They may not realize that adequate funds for the staffing of processing and public services activities must also be available. Realistic planning should provide some estimates, no matter how rough, of staff requirements. There are absolutely no firm guidelines for staffing as there are so many variables such as productivity of staff members, services demanded, amount of centralization, number of service points, and the quality of cataloging work. Some librarians, however, have rough rules of thumb which help. For instance, in Davis it is said that it takes about one person in the processing departments-acquisitions and catalogingto handle from eight hundred to nine hundred volumes in a year's time. It is further said that it takes about one person a year to check in at the kardex approximately three thousand to thirtythree hundred periodical issues and that about six thousand volumes can be prepared for binding a year by one person. In the circulation department about one staff member is needed for every two hundred to two hundred and forty students.

No general rule seems to work in connection with staffing for special services such as reference and documents. Much depends on the number of public desks covered, quality of service offered, needs of the academic program and other factors. However, over a period of years a library administrator, using intuitive techniques, can estimate fairly accurately what is needed.

Buildings. Planning for library buildings has been based almost entirely on standards listed in the previously noted Restudy of the Needs of California in Higher Education. In practice, the "restudy" standards have not been adequate for the housing of staff and nonbook materials. The newly devised Unit Area Allowance for Libraries will be a better guide.

One can sum up the Davis experience by saying that although there have been some mistakes, great progress has been made. In reviewing the experience, several admonitions come to mind for the benefit of library planners who find themselves in the same situation.

1. Planning. Library planning must be integrated with general planning for the university. General university planning 
must obviously come first and library planning second. Experience at Davis shows that institutions should plan carefully at least ten years ahead of time. An experienced library consultant and planner can often be used by an institution with great advantage.

2. Standards. Some basis for planning must exist. The standards and guidelines noted previously have been very helpful at Davis. Unfortunately, there are many aspects of library work for which widely accepted and tested standards do not exist. In many cases, an institution should prepare its own standards after a careful examination of local needs and after determining its long range goals. Particular care should be taken to see that book collection requirements and standards are firmly based on the academic program. Staffing requirements should not be ignored.

3. Funds. Funding requirements for university libraries are often much underestimated. Inflationary increases in book costs may not be anticipated. Staffing costs are usually higher than expected. Planners should estimate future library costs as well in advance as possible as obtaining adequate funds for a quality library requires much effort. Experienced consultants can be useful in estimating funds required for a library.

4. Organization of the library. Firm decisions about the organization of the library and about the administration of all library units on a campus must be made at an early date. An uncoordinated library system with numerous masters may never be effective no matter how much money is spent on it. Good sense and experience dictates that library services must be centralized as much as possible both administratively and physically.

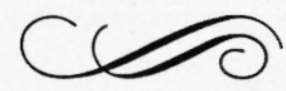

